\section{CURRENT PRACTICES OF HIGH AND LOW FLOW OXYGEN THERAPY AND HUMIDIFICATION IN UK NEONATAL UNITS}

P. Nath ${ }^{1}$, V. Ponnusamy ${ }^{1}$, K. Willis ${ }^{2}$, L. Bissett ${ }^{3}$, P. Clarke ${ }^{1}$

${ }^{1}$ Neonatal Intensive Care Unit, Norfolk and Norwich University Hospital NHS Trust, Norwich, ${ }^{2}$ Department of Paediatrics, Ipswich Hospital NHS Trust, Ipswich, ${ }^{3}$ Neonatal Unit, East and North Herts NHS Trust, Stevenage, UK

Background and aims: High flow (HF)nasal therapy delivers heated, humidified and blended oxygen/ air via small calibre nasal cannulae at flow rates of $>1 \mathrm{~L} / \mathrm{min}$. Cold, non-humidified gases delivered at $\mathrm{HF}$ rates may lead to significant dysfunction of the nasopharynx through drying and damage to the nasal mucosa. We aimed to examine current practices of humidification of HF and low flow (LF) nasal oxygen therapy in UK neonatal units.

Methods: Telephone questionnaire survey of all 214 UK neonatal units in July-November 09.

Results: Responses were obtained from 214(100\%) units. The Table summarises the data according to designation level of the neonatal units:

\begin{tabular}{|c|c|c|c|c|}
\hline & $\begin{array}{c}\text { Level 1 } \\
(\mathbf{n = 6 2})\end{array}$ & $\begin{array}{c}\text { Level 2 } \\
(\mathbf{n = 9 7})\end{array}$ & $\begin{array}{c}\text { Level 3 } \\
(\mathbf{n = 5 5})\end{array}$ & $\begin{array}{c}\text { All Units } \\
(\mathbf{n = 2 1 4})\end{array}$ \\
\hline Use HF & $\begin{array}{c}21 \\
(34 \%)\end{array}$ & $\begin{array}{c}51 \\
(52 \%)\end{array}$ & $\begin{array}{c}46 \\
(84 \%)\end{array}$ & $\begin{array}{c}118 \\
(55 \%)\end{array}$ \\
\hline $\begin{array}{c}\text { Humidify } \\
\text { HF }\end{array}$ & $\begin{array}{c}12 \\
(57 \%)\end{array}$ & $\begin{array}{c}39 \\
(76 \%)\end{array}$ & $\begin{array}{c}40 \\
(87 \%)\end{array}$ & $91(77 \%)$ \\
\hline Use LF & $\begin{array}{c}59 \\
(95 \%)\end{array}$ & $\begin{array}{c}97 \\
(100 \%)\end{array}$ & $\begin{array}{c}55 \\
(100 \%)\end{array}$ & $\begin{array}{c}211 \\
(98 \%)\end{array}$ \\
\hline $\begin{array}{c}\text { Humidify } \\
\text { LF }\end{array}$ & $\begin{array}{c}27 \\
(46 \%)\end{array}$ & $\begin{array}{c}50 \\
(51 \%)\end{array}$ & $\begin{array}{c}25 \\
(45 \%)\end{array}$ & $\begin{array}{c}102 \\
(48 \%)\end{array}$ \\
\hline
\end{tabular}

[Oxygen therapy and Humidification]

$\mathrm{LF}$ was defined as flow rates $\leq 1 \mathrm{~L} / \mathrm{min}, \mathrm{HF}$ as flow rates $>1 \mathrm{~L} / \mathrm{min}$

Level 1 units, special care; level 2 units, shortterm intensive care; level 3 units, full intensive and specialised care.

Conclusions: Wide variations exist in use of HF and LF oxygen therapy and humidification. Most UK units humidify HF oxygen, but fewer than half of UK units humidify LF oxygen. Future studies are needed to compare the incidence of nasopharyngeal staphylococcal colonisation/ infection in infants receiving humidified versus non-humidified HF and LF oxygen therapies.

1334

\section{FEASIBILITY TRIAL FOR THE DELIVERY OF LEVABUTEROL TO AN INFANT THROUGH AN ADAPTED HIGH FLOW NASAL CANNULA (HFNC) SYSTEM}

\author{
J. Rojas ${ }^{1}$, J. Cortez ${ }^{2}$, T. Miller²,3
}

${ }^{1}$ Neonatology, Baptist Hospital, Nashville, TN,

${ }^{2}$ Vapotherm, Inc, Stevensville, MD, ${ }^{3}$ Pediatrics, Jefferson Medical College, Philadelphia, PA, USA

Background and Aims: Albuterol derivatives are commonly used in the NICU to relieve airway constriction. Conventionally, these drugs are delivered while the patient is on a ventilator, or by face mask in non-intubated patients; however, for infants on HFNC the ability to deliver through the nasal prongs would limit discontinuation of therapy during drug dosing. The aim is to demonstrate that delivery of an aerosolized dose of Levabuterol through a HFNC system is feasible.

Methods: Two preterm infants were treated with Xopenex® aerosolized by 1) a small volume aerosol (tri-Anim) and airlife connector (Allegiance) while on a ventilator prior to extubation (VENT), and 2) after extubation using an ultrasonic nebulizer (Aerogen) on a HFNC system (Vapotherm Precision Flow ${ }^{\mathrm{TM}}$ ). Data for heart rate $(H R)$, respiratory rate $(R R)$, core temperature, $\mathrm{FIO} 2, \mathrm{SaO} 2$ and the ratio of FIO2:SaO2 were recorded 30 min before and 30 minutes after the administration.

Results: Both patients responded to the treatments in a similar manner. For both patients the HR increased by $12 \mathrm{bpm}$ on VENT and $10 \mathrm{bpm}$ with HFNC; RR decreased $6 \mathrm{br} / \mathrm{min}$ on VENT and $11 \mathrm{br} /$ min with $\mathrm{HFNC}$; core temperature decreased $0.16^{\circ} \mathrm{C}$ on VENT and increased $0.01^{\circ} \mathrm{C}$ with HFNC; FIO2 decreased $3.5 \%$ on VENT and $2.89 \%$ with HFNC; $\mathrm{SaO} 2$ increased $0.39 \%$ on VENT and $0.33 \%$ with HFNC; FIO2:SaO2 decreased 0.04 on VENT and 0.03 with HFNC.

Conclusions: Levabuterol delivery through a HFNC appears to have the same physiologic impact as delivery through a respirator. A larger study is warranted to substantiate these findings. 